\title{
A novel core@shell magnetic molecular imprinted nanoparticles for selective determination of folic acid in different food samples
}

\author{
Sajjad Hussain ${ }^{\mathrm{a}, \mathrm{b}}$, Sabir Khan ${ }^{\mathrm{a}}$, Saima Gul ${ }^{\mathrm{c}}$, Maria Isabel Pividori ${ }^{\mathrm{d}}$, Maria Del Pilar Taboada Sotomayor ${ }^{\mathrm{a}, *}$ \\ a Department of Analytical Chemistry, Institute of Chemistry, State University of São Paulo (UNESP), 14801-970 Araraquara, SP, Brazil \\ b Faculty of Material and Chemical Engineering,GIK Institute of Engineering Sciences and Technology, Topi, KPK 23460, Pakistan \\ c Department of Chemistry University of Swabi for Woman Gulo-Deri, Swabi, KPK, Pakistan \\ d Group de Sensors i Biosensors, Departament de Química, Universitat Autònoma de Barcelona (UAB), 08193, Bellaterra, Barcelona, Spain
}

\section{A R T I C L E I N F O}

\section{Article history:}

Received 11 February 2016

Received in revised form 7 June 2016

Accepted 22 July 2016

Available online 25 July 2016

\section{Keywords:}

Molecularly imprinted polymer

Folic acid

Magnetic nanoparticles

Food

\begin{abstract}
A B S T R A C T
In this work, magnetic molecularly imprinted polymers (MMIPs) were synthesized and tested for the determination of folic acid (FA) in different food samples. The MMIPs were polymerized at the surface of $\mathrm{Fe}_{3} \mathrm{O}_{4} @ \mathrm{SiO}_{2}$ magnetic nanoparticles (MNPs) using acrylonitrile (functional monomer), ethylene glycol dimethacrylate (EGDMA) as cross-linking agent and azobiisobutyronitrile (AIBN) as an radical initiator. The morphological, topological and chemical characteristics of the MMIPs were investigated by field emission scanning electron microscopy (FESEM), high resolution transmission electron microscopy (HRTEM) and Fourier transform infrared (FTIR) techniques. The physico-chemical characterization, such as adsorption capacities and selectivity of MMIPs was investigated and compared with the respective MNIPs. The adsorption experimental data demonstrate that maximum adsorption capacity of MMIP at equilibrium was $8 \mathrm{mg} \mathrm{g}^{-1}$ and than the adsorption process of FA over MMIPs follows Freundlich adsorption isotherm model and pseudo-first-order reaction kinetic. For evaluation of this new proposed material, the recovery studies were carried out in spiked samples at different concentration levels and the obtained values were in the range of $95-104 \%$ for orange and for spinach the recoveries were between 99.5 and $102.5 \%$. The relative standard deviations (RSD) for the recoveries were $<0.5 \%$ for both samples. These results demonstrate that this novel MMIP material can be efficiently used for the selective extraction of folic acid from different food complex matrices.
\end{abstract}

(c) 2016 Elsevier B.V. All rights reserved.

\section{Introduction}

Folic-acid (or folate) supplementation offers substantial and welldefined health benefits [1]. Numerous chronic diseases like gigantocytic anemia, leucopoenia, mentality devolution, psychosis; heart attack, malformation and neural tube defects during pregnancy are related due to the deficiency of folic acid (FA) [2]. Folic acid is found naturally in a wide variety of foods, including vegetables, fruits, poultry and meat [3]. It is necessary to monitor the quantity of FA in various food samples for their safety reasons. However, analysis of FA is not an easy task because of its presence in extremely lower concentration in biological systems, due to its lower stability under acidic conditions and its sensitiveness against light and high temperature [4]. Numerous methods have been used for the determination of FA including, spectrophotometry [5], flow injection chemiluminescence [6,7] fluorimetric [8], high-performance liquid chromatography (HPLC) [9,10], LC-MS $[11,12]$, electrochemical $[13,14]$ and capillary electrophoresis [15]. On the other hand microbiological assay of FA has widely been used, but

\footnotetext{
* Corresponding author.

E-mail addresses: mpilar@iq.unesp.br, mpilarts@hotmail.com (M. Del Pilar Taboada Sotomayor).
}

it is lengthy, time consuming, need extreme care and skill for its analysis [16].

Among the chromatographic techniques the LC-MS is believed to be the most efficient $[17,18]$. However, methods those based on chromatography, involve complexes pre-treatment, pre-concentration and extraction procedures [19]. Some of these methods used to determine folates in biological fluids and foods, using solid phase extraction (SPE) [20] for the pre-treatment of the samples, in which the adsorbent material is the unspecified organic functionalized silica C8 or C18.

In addition there is also exist a most cost-effective procedure for FA analysis, which is based on the enzyme protein-binding assay [21], but although the measurement is not influenced by the matrix effect, the corresponding kits have short self-life, due to the biological material used in the detection.

In this sense, aim at more easy, rapid and efficient pre-treatment of complex samples, our research group have proposed the development of magnetic nanoparticles coated with MIPs for different analytes than can be used to separate and concentrate chemicals conveniently using a simple external magnetic field from a Neodimium magnet. Therefore, a combination of molecular imprinting technology would provide a powerful analytical tool with all desirables characteristics, besides being more selective than traditional silica adsorbent materials [22, 
23]. Thus, continuing the dissemination of the results of our research group, in this article we report the successful synthesis, characterization and application of a novel magnetic material based on magnetic nanoparticles coated with MIP selective to folic acid molecule.

\section{Materials and methods}

\subsection{Reagents}

Folic acid, $\mathrm{FeCl}_{2} \cdot 4 \mathrm{H}_{2} \mathrm{O}$ (98\%), $\mathrm{FeCl}_{3} \cdot 6 \mathrm{H}_{2} \mathrm{O}$ (97\%), tetraethoxysilane (TEOS), acrylonitrile

$(\geq 99 \%)$, [3(methacryloyloxy)propyl]trimethoxysilane (MPS), methylacrylic acid (MAA), ethylene glycol dimethacrylate (EGDMA), 2,2'azobisisobutyronitrile (AIBN), were provided by Sigma-Aldrich. $\mathrm{NH}_{4} \mathrm{OH}, \mathrm{NaOH}$ and $\mathrm{H}_{2} \mathrm{SO}_{4}$ were obtained from Synth-Brazil. Acetonitrile (ACN), ethanol, methanol (HPLC grade) and acetic acid (glacial, 100\%), were purchased from Panreac Quimica. All the reagents used without prior purification and solutions were prepared in deionized water ( $18 \mathrm{M} \Omega$ at $25^{\circ} \mathrm{C}$ ) obtained from Milli-Q Direct-0.3 (Millipore) purification system.

\subsection{Preparation of magnetic nanoparticles $\left(\mathrm{Fe}_{3} \mathrm{O}_{4}\right)$ and $\mathrm{Fe}_{3} \mathrm{O}_{4} @ \mathrm{SiO}_{2}$}

Magnetic nanoparticles were prepared by co-precipitation method as described by Lu et al. [24] A known amount of both $\mathrm{FeCl}_{2} \cdot 4 \mathrm{H}_{2} \mathrm{O}$ and
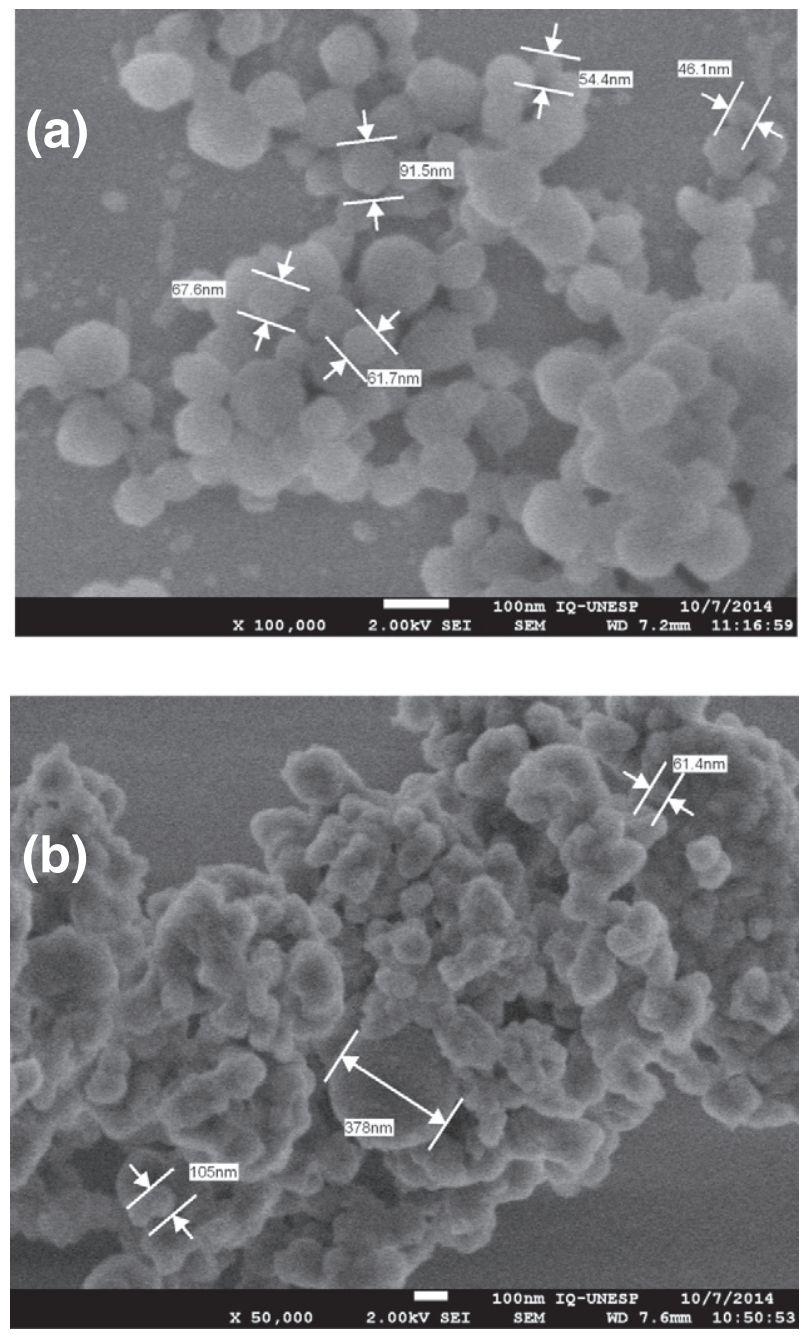

Fig. 1. Scanning electron microscopy images of MMIPs (a) and MNIPs, with their respective particles sizes.
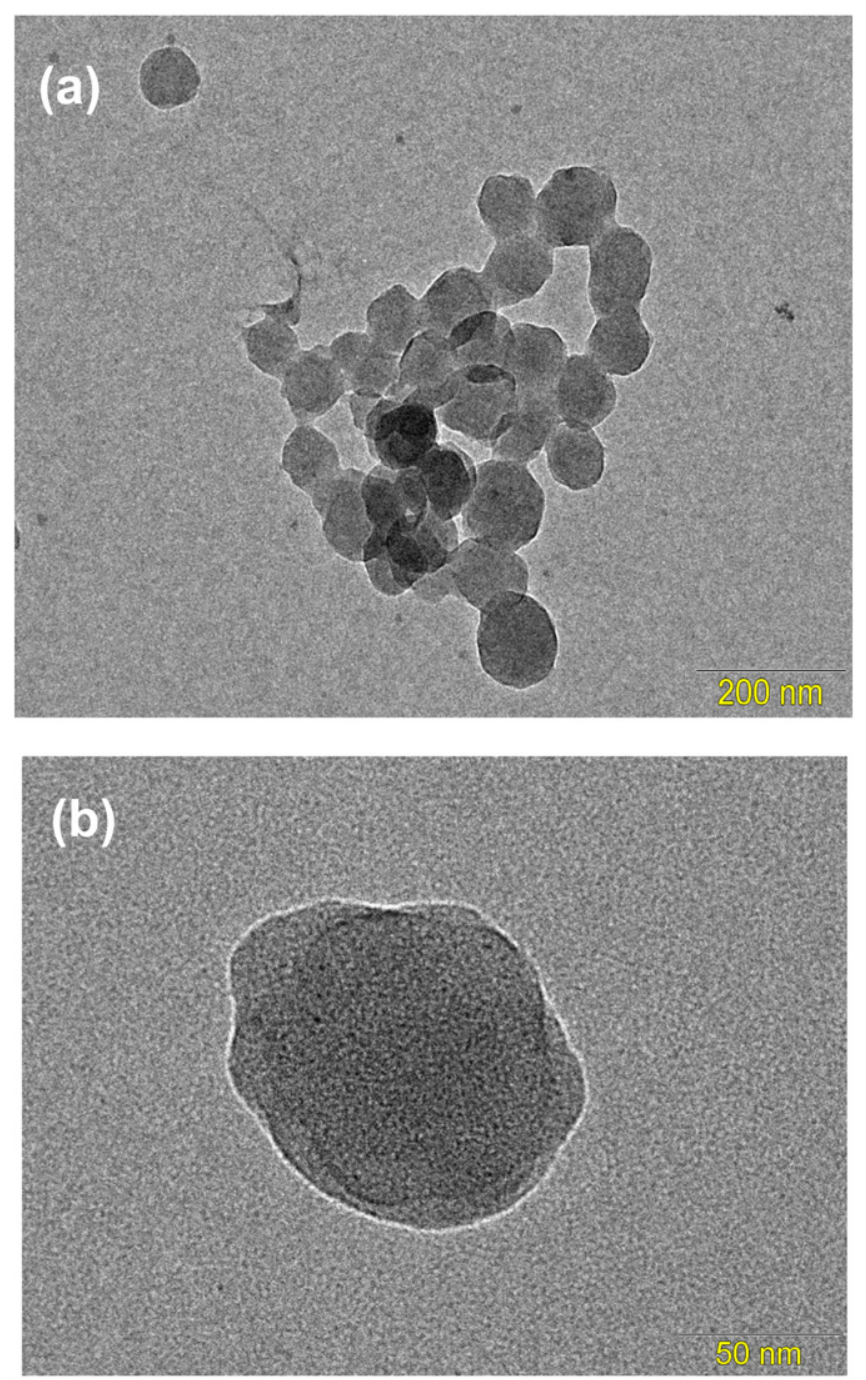

Fig. 2. Transmission electron microscopy (TEM) of magnetic molecular imprinted polymer (MMIP) for folic acid at two different scales.

$\mathrm{FeCl}_{3} \cdot 6 \mathrm{H}_{2} \mathrm{O}$ were dissolved in $80 \mathrm{~mL}$ of water with vigorous stirring in nitrogen atmosphere. $\mathrm{NH}_{4} \mathrm{OH}(10 \mathrm{~mL})$ drop wise was added in the system and the reaction was maintained at $80{ }^{\circ} \mathrm{C}$ for 30 min. The black

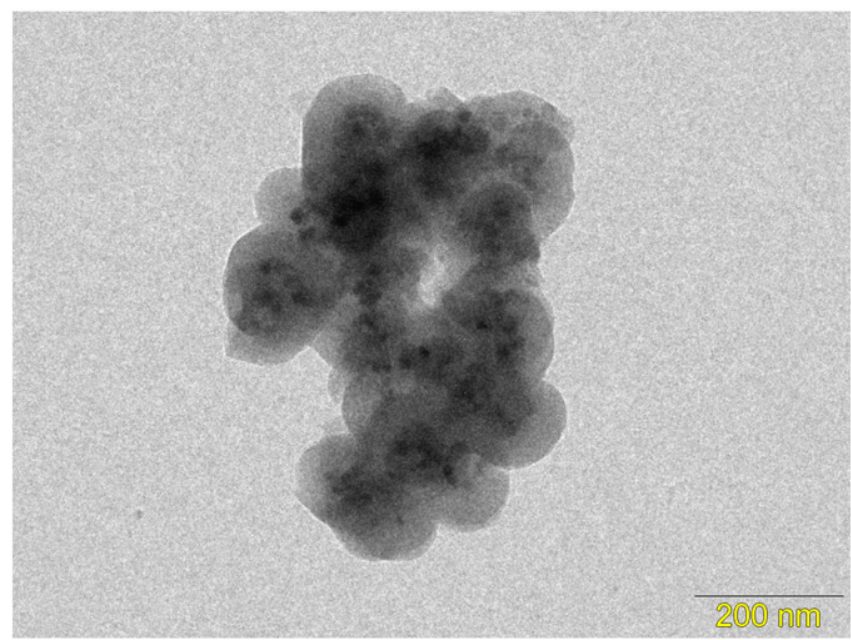

Fig. 3. Transmission electron microscopy (TEM) of magnetic molecular non-imprinted polymer (MNIP). 


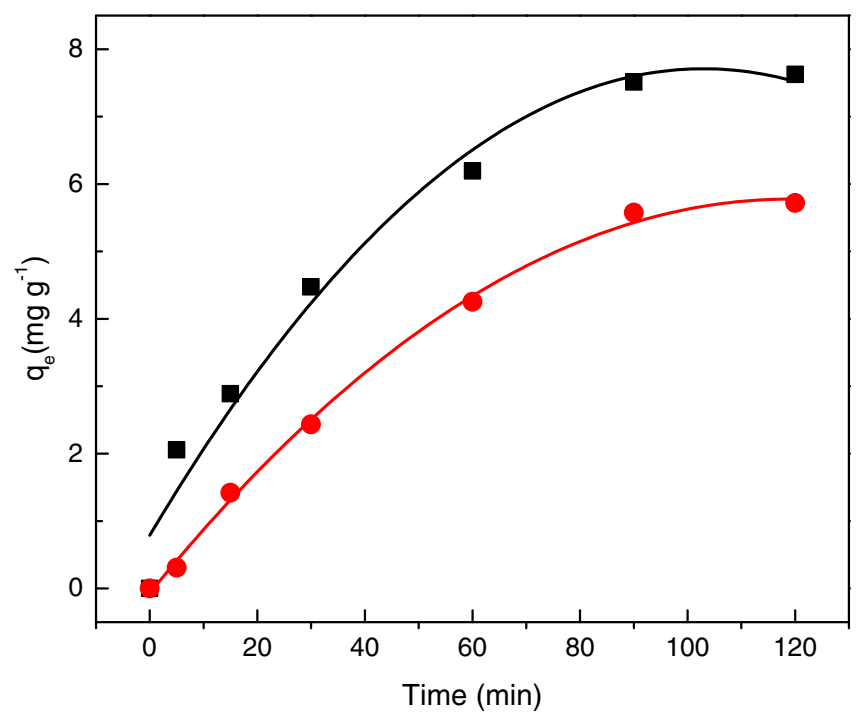

Fig. 4. Binding capacity of folic acid vs time on to MMIPs (匹) and MNIPs (•).

precipitation of $\mathrm{Fe}_{3} \mathrm{O}_{4}$ nanoparticles was separated with a permanent magnet and washed thoroughly with deionized water to remove the unreacted chemicals, and then dried in the vacuum. $300 \mathrm{mg} \mathrm{Fe}_{3} \mathrm{O}_{4}$ nanoparticles were dispersed in $40 \mathrm{~mL}$ of ethanol (EtOH) and $4 \mathrm{~mL}$ of deionized water by ultra-sonication for $15 \mathrm{~min}$ and then followed by the addition of $5 \mathrm{~mL}$ of $\mathrm{NH}_{4} \mathrm{OH}$ and $2 \mathrm{~mL}$ of tetraethoxysilane (TEOS). The mixture was left to react for $12 \mathrm{~h}$ at the room temperature. The products were collected by magnetic separation and was washed with deionized water three times and then dried in the vacuum. In the next step $\mathrm{Fe}_{3} \mathrm{O}_{4} @ \mathrm{SiO}_{2}$ nanoparticles were modified by 3metacriloxipropiltrimetoxissilano (MPS) by taking $250 \mathrm{mg}$ of the $\mathrm{Fe}_{3} \mathrm{O}_{4} @ \mathrm{SiO}_{2}$ nanoparticles was dispersed in $50 \mathrm{~mL}$ of anhydrous toluene containing $5 \mathrm{~mL}$ of 3-metacriloxipropiltrimetoxissilano (MPS) and the mixture was allowed to react for $12 \mathrm{~h}$ in dry nitrogen atmosphere. The obtained product was separated by an external magnet and dried in vacuum.

\subsection{Preparation of MMIPs and MNIPS}

MMIPs were prepared by polymerization of $0.2 \mathrm{mmol}$ of folic acid (FA), $0.8 \mathrm{mmol}$ of monomer (Acrylonitrile, Supplementary data) in ethanol $(30 \mathrm{~mL})$. The mixture was shaken in a water bath at $25^{\circ} \mathrm{C}$ for $12 \mathrm{~h}$, then $200 \mathrm{mg} \mathrm{Fe} \mathrm{O}_{4} @ \mathrm{SiO}_{2}-\mathrm{C}=\mathrm{C}$ were added into the reaction system and was shaken for more $3 \mathrm{~h}$. Furthermore, $4.0 \mathrm{mmol}$ of EGDMA and $0.05 \mathrm{mmol}$ of AIBN were added into the system and the mixture was sonicated for $5 \mathrm{~min}$ in nitrogen atmosphere, and the reaction mixture was left at $60{ }^{\circ} \mathrm{C}$ under nitrogen gas protection for $24 \mathrm{~h}$. After polymerization, the template molecule was leached out by Soxhlet extraction using methanol: acetic acid (9:1, v/v) as eluent, and the eluent was replaced every $12 \mathrm{~h}$. The template (Folic acid) had been determined using HPLC in eluent at the interval of $12 \mathrm{~h}$. After complete removal of template molecule the products (MMIPs) were dried at $40{ }^{\circ} \mathrm{C}$ under

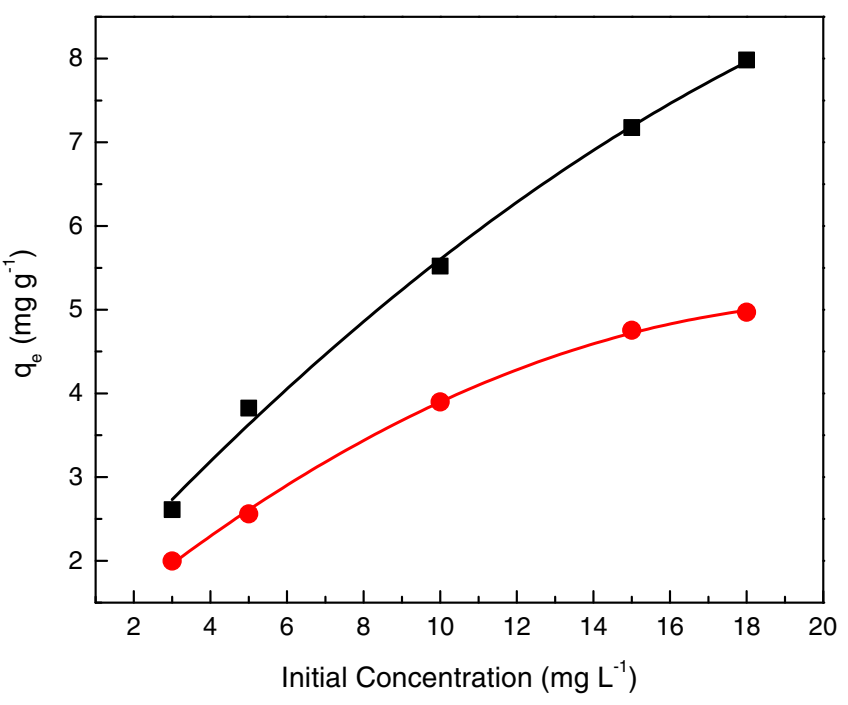

Fig. 5. Binding capacity of folic acid onto MMIPs $(\square)$ and MNIPs $(\bullet)$ at different initial concentrations $\left(\mathrm{C}_{\mathrm{i}}\right)$.

vacuum. Similarly magnetic non-molecular imprinted polymers (MNIPs) were prepared under the same conditions as described above without analyte.

\subsection{Folic acid solution and food samples}

A stock solution of FA ( $\mathrm{pH}$ 6.5) was prepared by dissolving $10 \mathrm{mg}$ FA in $100 \mathrm{~mL}$ of deionized water with a few drops of $0.1 \mathrm{~mol} \mathrm{~L}^{-1} \mathrm{NaOH}$, the prepared solution stored in a dark flask and kept in a refrigerator to prevent degradation. All working solutions of FA were prepared daily by appropriate dilution and the $\mathrm{pH}$ was adjusted to 6.5 with the help of $0.1 \mathrm{~mol} \mathrm{~L}^{-1} \mathrm{NaOH}$.

The spinach, and orange were purchased from a local supermarket in Araraquara in the state of São Paulo - Brazil. The spinach samples were prepared as previously described [25]. A $50.0 \mathrm{~g}$ of real sample (spinach) was cut into small pieces using a razor blade, and was boiled with water under reflux for $50 \mathrm{~min}$. The mixture was cooled and filtered through a membrane filter. A suitable aliquot of the filtrate was used to determine folic acid. The orange juice was obtained by squeezing fresh orange by manual orange juice extractor. The orange juice was first filtered using semi-analytical whatman paper, after this it was filtered using Millipore membrane of $0.45 \mathrm{~mm}$ and the filtrate was stored in refrigerator for using it in further analysis [26].

\subsection{Binding and selective adsorption experiments}

To evaluate the binding capacity of prepared MMIPs and MNIPs adsorption tests were carried out, by adding $10 \mathrm{mg}$ of MMIPs and MNIPs in a separated $20 \mathrm{~mL}$ glass vial and adds $10.0 \mathrm{~mL}$ of $10 \mathrm{mg} \mathrm{L}^{-1}$ of the folic acid solutions. The mixture was shaken in a rotating shaker for $120 \mathrm{~min}$ and after being shaken the magnetic polymer suspensions were separated by magnetic bar and filtered with a $0.45 \mu \mathrm{m}$ membrane for HPLC

Table 1

The rate constant and binding capacity for the sorption of ametryne.

\begin{tabular}{|c|c|c|c|c|c|c|}
\hline \multicolumn{4}{|c|}{ Pseudo first order kinetic model } & \multicolumn{3}{|c|}{ Pseudo second order kinetic model } \\
\hline Sorbents & $\mathrm{q}_{\mathrm{e}}\left(\mathrm{mg} \mathrm{g}^{-1}\right)$ & $\mathrm{R}^{2}$ & $\mathrm{k}_{1}\left(\mathrm{mg} \mathrm{g}^{-1} \min ^{-1}\right)$ & $\overline{\mathrm{q}_{\mathrm{e}}\left(\mathrm{mg} \mathrm{g}^{-1}\right)}$ & $\mathrm{R}^{2}$ & $\overline{\mathrm{k}_{2}\left(\mathrm{mg} \mathrm{g}^{-1} \min ^{-1}\right)}$ \\
\hline MIP & 7.510 & 0.9936 & 0.0252 & 9.432 & 0.9756 & 0.00379 \\
\hline NIP & 5.575 & 0.9902 & 0.0236 & 10.20 & 0.9506 & 0.00133 \\
\hline
\end{tabular}




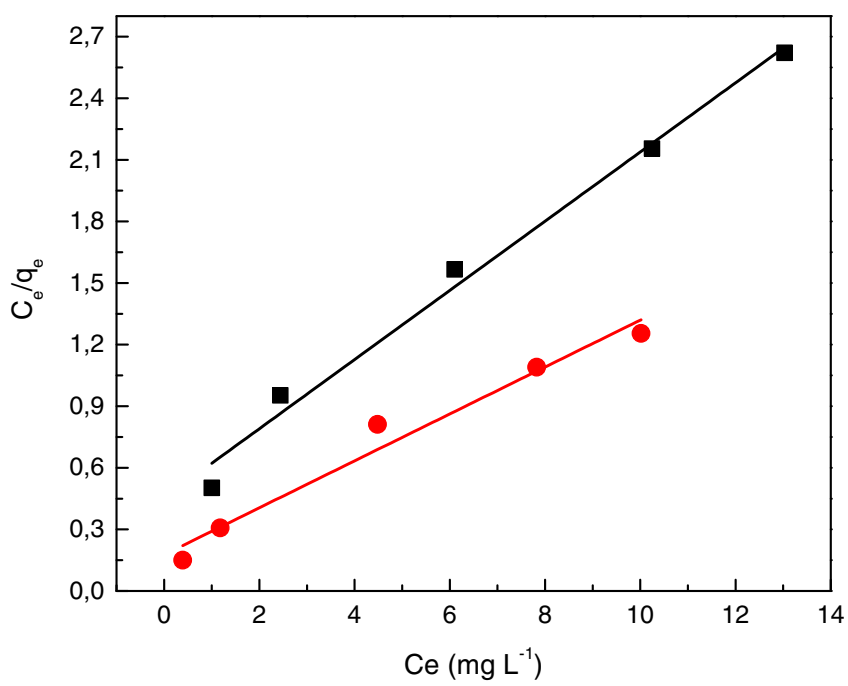

Fig. 6. Langmuir model fit for the adsorption of folic acid onto MMIPs ( $\mathbf{\square})$ and MNIPs $(\bullet)$ material.

analysis. The binding capacity is calculated using by the Eqs. (1) and (2) $[27,28]$.

$\mathrm{Q}_{\mathrm{t}}=\frac{\left(\mathrm{C}_{\mathrm{o}}-\mathrm{C}_{\mathrm{e}}\right) \mathrm{V}}{\mathrm{m}}$

$\mathrm{Q}_{\mathrm{e}}=\frac{\left(\mathrm{C}_{\mathrm{t}}-\mathrm{C}_{\mathrm{e}}\right) \mathrm{V}}{\mathrm{m}}$

$\mathrm{Q}_{t}\left(\mathrm{mg} \mathrm{g}^{-1}\right)$ is the experimental adsorption quantity at time $t, \mathrm{Q}_{\mathrm{e}}$ $\left(\mathrm{mg} \mathrm{g}^{-1}\right)$ equilibrium adsorption quantity, $\mathrm{C}_{\mathrm{o}}\left(\mathrm{mg} \mathrm{L}^{-1}\right)$ is the initial concentration of $\mathrm{FA}, \mathrm{Ce}\left(\mathrm{mg} \mathrm{L}^{-1}\right)$ is the equilibrium concentration, $\mathrm{Ct}$ is the final concentrations $\left(\mathrm{mg} \mathrm{L}^{-1}\right), \mathrm{V}(\mathrm{mL})$ is the volume of FA solution and $\mathrm{m}(\mathrm{g})$ is the weight of MMIPs and MNIPs. All the experiments were performed in triplicate.

\subsection{Instruments and analytical methods of analysis}

The chromatographic analyses were performed using a Shimadzu Model 20A liquid chromatograph, coupled to an SPD-20A UV/Vis detector, a SIL-20A autosampler and a DGU-20A5 degasser. The chromatography system was controlled by a microcomputer and the C18 column $(250 \mathrm{~mm} \times 4.6 \mathrm{~m})$ was used in the analysis. The chromatographic conditions used were, mobile phase composed of a mixture of acetinitonitryle:water $(90: 10, \mathrm{v} / \mathrm{v})$, flow rate of $1.0 \mathrm{~mL} \mathrm{~min}^{-1}$, sample injection volume of $20 \mu \mathrm{L}$ and wavelength of $280 \mathrm{~nm}$ for folic acid detection.

FTIR-VERTEX 70 spectrometer (BRUKER) with spectral range of 4000 to $370 \mathrm{~cm}^{-1}$ and a detector of DLaTGS was employed to examine the FTIR spectra of mag-MIPs and Mag-NIPs.

The size and surface morphology of nanoparticle samples were analyzed using field emission gun scanning electron microscope (FEG-SEM; JEOL model 7500F) (Germany) GmbH. TEM analysis were performed using high resolution transmission electron microscope HR-TEM (Philips- model CM200 supertwin with resolution of 1.9 A.

\section{Result and discussion}

\subsection{Morphologic characterization}

The structures of MMIPs and MNIPS were well characterized by Field Emission Scanning electron microscopy (FESEM) and high-resolution transmission electron microscope (HRTEM). It could be seen from the Fig. 1 that the MMIPs were all spherical shape and the size of the particles was in the range of 50-100 nm (Fig. 1a). However, in Fig. 1b, corresponding to MNIP could be observed irregular spheres with a high degree of agglomeration and a roughness in the surface.

The TEM analysis further reveals that magnetic-nanoparticles were of spherical shape with approximately $100 \mathrm{~nm}$ in diameter, such suggest for the SEM images. It is evident in Fig. $2 b$ than the core-shell structure of MMIPs was successfully constructed, since the double circle of microsphere indicates that in fact was obtained a core-shell particle of $\mathrm{Fe}_{3} \mathrm{O}_{4} @ \mathrm{MIP}$ (MMIP), in wich can be clearly seen the $\mathrm{SiO}_{2}$-MIP shell uniformly coating the $\mathrm{Fe}_{3} \mathrm{O}_{4}$ dark core, which for their small size was very helpful for more recognition sites and higher adsorption capacity of the template molecule, due to the high active area.

On the other hand, TEM images of MNIPs show aggregates of the nanoparticles (Fig. 3) from which it can be clearly distinguished a relatively large mesosphere of aggregates of fine particles with sizes c.a. $200 \mathrm{~nm}$, which also confirms the SEM results.

\subsection{Effect of contact time on the adsorption of folic acid onto MMIPs and MNIPS}

The effect of contact time on the adsorption of FA was studied. As shown in Fig. 4 the adsorption increases with time, and was rapid in the initial $60 \mathrm{~min}$ and then continued slowly. The $90 \mathrm{~min}$ was taken as equilibrium time. Initially a large numbers of active sites are expected to be available on the surface of MMIPs and MNIPs. As the adsorption progresses the sites become saturated and rate of adsorption decreased and get covered and there is no free space is available to the adsorbate molecules. The initial rapid uptake of (upto $60 \mathrm{~min}$ ) FA from solution was likely due to more exposed binding sites and the slow sorption phase likely resulted from more internal binding sites. Due to high surface area of MMIPs shows maximum adsorption than MNIPs for the FA.

\subsection{Adsorption kinetics}

In order to investigate the kinetics of adsorption of FA on MMIPs and MNIPs, the pseudo-first-order and pseudo-second-order equations [29] were applied. The pseudo-first-order expression is given by Eq. (3).

$\log \left(\mathrm{q}_{\mathrm{e}}-\mathrm{q}_{\mathrm{t}}\right)=-\frac{\mathrm{k}_{1} \mathrm{t}}{2.303}+\log \mathrm{q}_{\mathrm{e}}$

Where $\mathrm{q}_{\mathrm{e}}$ is the amount of adsorption of FA ( $\mathrm{mg} \mathrm{g}^{-1}$ ) adsorbed at equilibrium and at time qt (minutes) respectively. $\mathrm{k}_{1}$ is overall rate constant. Straight lines were obtained by plotting $\log \left(\mathrm{q}_{\mathrm{e}}-\mathrm{q}_{\mathrm{t}}\right)$ against $\mathrm{t}$, as shown in Fig. S2. The values of rate constant $k_{1}$ were calculated from the slopes of straight lines of Fig. S2 and the values are reported in Table 1.

Table 2

Data obtained used the Langmuir and Freundlich isotherm models applied in our experimental results.

\begin{tabular}{|c|c|c|c|c|c|c|}
\hline \multicolumn{4}{|c|}{ Langmuir isotherm equation } & \multicolumn{3}{|c|}{ Freundlich isotherm equation } \\
\hline Sorbents & $\mathrm{q}_{\mathrm{e}}\left(\mathrm{mg} \mathrm{g}^{-1}\right)^{*}$ & $\mathrm{R}^{2}$ & $\overline{\mathrm{K}_{1}\left(\mathrm{~L} \mathrm{mg}^{-1}\right)}$ & $\overline{\mathrm{R}^{2}}$ & $1 / \mathrm{n}$ & $\mathrm{K}\left(\mathrm{mg} \mathrm{g}^{-1}\right)\left(\mathrm{L} \mathrm{mg}^{-1}\right)^{1 / n}$ \\
\hline MIP & 8.757 & 0.9639 & 0.646 & 0.9910 & 0.3357 & 3.557 \\
\hline NIP & 5.938 & 0.9861 & 0.380 & 0.9886 & 0.3738 & 1.940 \\
\hline
\end{tabular}

* $\mathrm{q}_{\mathrm{e}}\left(\mathrm{mg} \mathrm{g}^{-1}\right)$ is calculated from Langmuir isotherm equation (Eq. 5). 


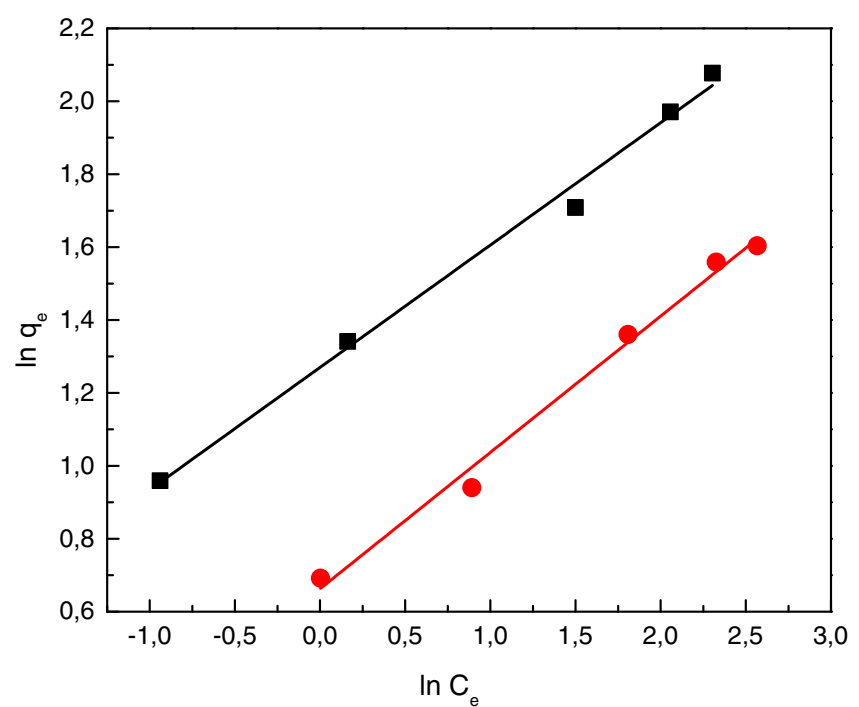

Fig. 7. Freundlidch model fit for the adsorption of folic acid onto MMIPs ( $\mathbf{\square})$ and MNIPs $(\bullet)$ materials.

The pseudo-second order kinetics model in Eq. (4).

$\frac{\mathrm{t}}{\mathrm{q}_{\mathrm{t}}}=\frac{1}{\mathrm{k}_{2} \mathrm{q}_{\mathrm{e}}^{2}}+\frac{1}{\mathrm{q}_{\mathrm{e}}} \mathrm{t}$

where $\mathrm{q}_{\mathrm{e}}$ is the maximum adsorption capacity $\left(\mathrm{mol} \mathrm{g}^{-1}\right)$ for the pseudo-second-order adsorption, $\mathrm{q}_{\mathrm{t}}$ the amount of the FA adsorbed at time $\mathrm{t}\left(\mathrm{mol} \mathrm{g}^{-1}\right), \mathrm{k}_{2}$ the equilibrium rate constant of pseudo-second-order adsorption $\left(\mathrm{mg} \mathrm{g}^{-1} \mathrm{~min}^{-1}\right.$ ). The values of $\mathrm{k}_{2}$ and $\mathrm{q}_{\mathrm{e}}$ were calculated from the plot of $t / q_{t}$ against $t$ (Fig. S3). The calculated $q_{e}$ values agree with experimental $q_{e}$ values, and also, the correlation coefficients $\left(R^{2}\right)$ for the pseudo-first-order kinetic plots at all the studied concentrations were above 0.9936 for MMIPs and 0.9902 for MNIPs (Table 1 ). These results imply that the adsorption system studied obeys to the pseudofirst-order-kinetic model.

\subsection{Study of the folic acid onto MMIPs and MNIPs by adsorption isotherms}

In order to study the effect of the FA adsorption in the MMIP and their corresponding MNIP, experiments were conducted at a fixed adsorbent dosage of $10 \mathrm{mg}$ at different initial concentration $\left(\mathrm{C}_{\mathrm{i}}\right)$. The results obtained from these experiments are given in Fig. 5 in which possible to observe that the adsorption increases as the FA concentration increases which mainly due to the availability of large number of site over the surface at certain level and after that the sorption capacity slightly decreases because the adsorption site become saturated with FA molecules. It's also obvious that quantity adsorbed by MMIP was more than the MNIP, which proposed that imprinted sites molded due to the reaction of imprinting and crosslinking. This also demonstrates

Table 3

Recovery results obtained for the analysis of folic acid collected from the supermarkets of the city of Araraquara-SP.

\begin{tabular}{lllll}
\hline $\begin{array}{l}\text { FA add }(\mathrm{mg} \\
\left.\mathrm{L}^{-1}\right)\end{array}$ & $\begin{array}{l}\text { Orange juice FA } \\
\text { found }\end{array}$ & $\begin{array}{l}\text { Recovery } \\
(\%)\end{array}$ & $\begin{array}{l}\text { Spinach FA } \\
\text { found }\end{array}$ & $\begin{array}{l}\text { Recovery } \\
(\%)\end{array}$ \\
\hline 0 & $0.15 \pm 0.05$ & - & $0.09 \pm 0.03$ & - \\
2 & $1.90 \pm 0.03$ & 95.0 & $2.05 \pm 0.04$ & 102.5 \\
4 & $4.10 \pm 0.11$ & 102.5 & $4.07 \pm 0.06$ & 101.8 \\
6 & $6.13 \pm 0.17$ & 102.2 & $6.10 \pm 0.02$ & 101.7 \\
8 & $8.33 \pm 0.20$ & 104.1 & $7.96 \pm 0.06$ & 99.5 \\
10 & $9.55 \pm 0.36$ & 95.6 & $10.1 \pm 0.1$ & 101.1 \\
12 & $11.96 \pm 0.41$ & 99.7 & $12.1 \pm 0.1$ & 101.1 \\
\hline
\end{tabular}

that initial FA concentration plays an important role in the adsorption process.

Since the determination of adsorption isotherm is important in designing the nature of adsorption system, two widely used isotherm models have been applied. The data were evaluated by applying the Langmuir (5) and Freundlich (6) isotherms.

For the Langmuir model was used the Eq. (5) follow:

$\frac{\mathrm{C}_{\mathrm{e}}}{\mathrm{q}_{\mathrm{e}}}=\frac{1}{\mathrm{~K}_{1} \mathrm{X}_{\mathrm{m}}}+\frac{\mathrm{C}_{\mathrm{e}}}{\mathrm{X}_{\mathrm{m}}}$

where $C_{e}$ is the equilibrium concentration of $F A\left(\mathrm{mg} \mathrm{L}^{-1}\right), \mathrm{q}_{\mathrm{e}}$ is the amount $\left(\mathrm{mg} \mathrm{g}^{-1}\right)$ of FA adsorbed; $\mathrm{X}_{\mathrm{m}}\left(\mathrm{mg} \mathrm{g}^{-1}\right)$ is adsorption capacity (amount od adsorbate adsorbed per unit mass of the FA) and $K_{1}$ is Langmuir constants, representing the adsorption capacity $\left(\mathrm{mg} \mathrm{g}^{-1}\right)$ respectively [30] [31].

Straight lines were obtained by plotting $C_{e} / q_{e}$ against $C_{e}$ as shown in Fig. 6 the linear plots indicate the applicability of Langmuir adsorption isotherm, consequently the formation of monolayer surface of the adsorbate on the surface of the adsorbent. Langmuir constant $\mathrm{k}_{1}$ and $\mathrm{X}_{\mathrm{m}}$ maximum adsorption capacity were calculated from the slopes and intercepts of plots and are given in Table 2.

The Freundlich isotherm is an empirical equation employed to describe the heterogeneous system. The linear form of Freundlich isotherm was also applied to the adsorption of FA.

$\ln \frac{x}{m}=\ln K+\frac{1}{n} \ln C_{e}$

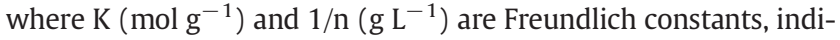
cating the adsorption capacity and adsorption intensity respectively. $\mathrm{x} / \mathrm{m}$ adsorption per gram of adsorbent which is obtained by dividing the amount of adsorbate $(\mathrm{x})$ by the weight of the adsorbent $(\mathrm{m})$. Straight lines were obtained by plotting $\ln \mathrm{x} / \mathrm{m}$ against $\ln \mathrm{C}_{\mathrm{e}}$ and $\mathrm{K}$ and $1 / \mathrm{n}$ were calculated from the slope and intercept of these lines (Fig. 7). The values of Freundlich constants are given in Table 2 For favorable adsorption, the value of $1 / \mathrm{n}$ is smaller than 1 and when the unfavorable adsorption takes place, the adsorption bond becomes weak and the value of $1 / \mathrm{n}$ is $>1$, so adsorption decreases. As shown in Table 2 that the value of $1 / \mathrm{n}$ for FA adsorption is less than unity, which shows high adsorption intensity. The correlation coefficient is more close to 1 for the Freundlich isotherm that indicates good agreement with experimental data and isotherm parameters, however it is important to emphasize that the MAC value obtained by the Langmuir isotherm $\left(8.757 \mathrm{mg} \mathrm{g}^{-1}\right)$ is very close that experimental value of Fig. 5 ( $8.1 \mathrm{mg} \mathrm{g}^{-1}$ ) indicating that this adjustment despite not being the best is also valid.

\subsection{Application of the material}

In order to applied the material to the samples, MMIPs was used as a adsorbent material used $10 \mathrm{mg}$ of MMIP on a SPE system. For this, $100.0 \mathrm{~mL}$ of the filtrate of orange or spinach were spiked with 2$12 \mathrm{mg} \mathrm{L}^{-1}$ of FA solution and passed through the packed-bed column at $1 \mathrm{~mL} \mathrm{~min}^{-1}$ flow rate. After preconcentration step, the MMIPs retained on the column was eluted with $10 \mathrm{~mL}$ of $\mathrm{CH}_{3} \mathrm{OH}$ at $0.5 \mathrm{~mL} \mathrm{~min}^{-1}$ flow rate followed by injection of eluent in the HPLC system. As it is observed that preconcentration procedure enhances the chromatographic peak of MMIPs and promotes a cleanup of the sample. The recovery values were obtained in the range of $95-104 \%$ for orange samples and for spinach sample good recovery were obtained in the range of 99.5-102.5. The recoveries obtained are shown in the Table 3. This excellent results can be attributed to than in the MMIP the imprinted sites are situated on the surface of imprinting materials and this property allows them have a higher sorption ability. In addition the magnetic property allows will perform the steps of pre- 
concentration and extraction of the analyte from complex samples in a more simple way, since the inherent characteristics of the magnetic particle in separations will be used.

\section{Conclusions}

The MMIPs and MNIPs using Folic acid as template prepared under the same surface imprinting conditions which showed fast adsorption kinetics and selective recognition affinity in aqueous solution of folic acid. The surface molecularly imprinted magnetic microspheres possessed rapid dynamic adsorption, high adsorption ability and suitable repeatability. The percentage recovery for orange juice were obtained from 95.00 to 104.10 while for Spinach samples were obtained in the range of 99.50 to 102.50 . The presented MMIPs extraction method had the characters of simplicity, rapidity and selectivity, while the application of this method provided a new promising alternative for simultaneous removal of folic acids in food matrices.

\section{Acknowledgments}

This project was financially supported by the National Council of Scientific and Technological Development (CNPq) Process no 400459/ 2012-4 and 150412/2014-2.

\section{Appendix A. Supplementary data}

Supplementary data to this article can be found online at http://dx. doi.org/10.1016/j.reactfunctpolym.2016.07.011.

\section{References}

[1] M. Behpour, A.M. Attaran, M.M. Sadiany, A. Khoobi, Adsorption effect of a cationic surfactant at carbon paste electrode as a sensitive sensor for study and detection of folic acid, Measurement 77 (2016) 257-264, http://dx.doi.org/10.1016/j. measurement.2015.09.009.

[2] H. Beitollahi, M. Hamzavi, M. Torkzadeh-Mahani, Electrochemical determination of hydrochlorothiazide and folic acid in real samples using a modified graphene oxide sheet paste electrode, Mater. Sci. Eng. C 52 (2015) 297-305, http://dx.doi. org/10.1016/j.msec.2015.03.031.

[3] C. Ralph, Folic Acid, in: M. Shils, M. Shike, A.C. Ross, B. Caballero, J.R. Cousins (Eds.), Mod. Nutr. Heal. Dis., 50 Anniver, Lippincott Williams \& Wilkins, Baltimore 2005, pp. $470-481$.

[4] J. Arcot, A. Shrestha, Folate: methods of analysis, Trends Food Sci. Technol 16 (2005) 253-266, http://dx.doi.org/10.1016/j.tifs.2005.03.013.

[5] R. Matias, P.R.S. Ribeiro, M.C. Sarraguça, J.A. Lopes, A UV spectrophotometric method for the determination of folic acid in pharmaceutical tablets and dissolution tests, Anal. Methods 6 (2014) 3065, http://dx.doi.org/10.1039/c3ay41874j.

[6] Y.D. Liang, J.F. Song, X.F. Yang, Flow-injection chemiluminescence determination of fluoroquinolones by enhancement of weak chemiluminescence from peroxynitrous acid, Anal. Chim. Acta 510 (2004) 21-28, http://dx.doi.org/10.1016/j.aca.2003.12. 054.

[7] S.M. Wabaidur, S.M. Alam, S.H. Lee, Z.A. Alothman, G.E. Eldesoky, Chemiluminescence determination of folic acid by a flow injection analysis assembly, Spectrochim. Acta A Mol. Biomol. Spectrosc. 105 (2013) 412-417, http://dx.doi.org/10.1016/j.saa. 2012.11.078.

[8] J.L. Manzoori, A. Jouyban, M. Amjadi, J. Soleymani, Spectrofluorimetric determination of folic acid in tablets and urine samples using 1,10-phenanthroline-terbium probe, Luminescence 26 (2011) 106-111, http://dx.doi.org/10.1002/bio.1191.

[9] J. Alaburda, A.P. de Almeida, L. Shundo, V. Ruvieri, M. Sabino, Determination of folic acid in fortified wheat flours, J. Food Compos. Anal 21 (2008) 336-342, http://dx. doi.org/10.1016/j.jfca.2007.12.002.

[10] P. Jin, L. Xia, Z. Li, N. Che, D. Zou, X. Hu, Rapid determination of thiamine, riboflavin, niacinamide, pantothenic acid, pyridoxine, folic acid and ascorbic acid in vitamins with minerals tablets by high-performance liquid chromatography with diode array detector, J. Pharm. Biomed. Anal 70 (2012) 151-157, http://dx.doi.org/10. 1016/j.jpba.2012.06.020.

[11] M. Zhang, L. Quan, X. Lu, Y. Bao, L. Wu, L. Zhang, et al., Hypomethylation of fetal brain genomic DNA in neural tube defects determined by a new liquid chromatography-electrospray ionization tandem mass spectrometry (LC-MS/MS) method, Anal. Methods 4 (2012) 2515, http://dx.doi.org/10.1039/c2ay25140j.

[12] B.C. Nelson, K.E. Sharpless, L.C. Sander, Quantitative determination of folic acid in multivitamin/multielement tablets using liquid chromatography/tandem mass spectrometry, J. Chromatogr. A 1135 (2006) 203-211, http://dx.doi.org/10.1016/j. chroma.2006.09.040.

[13] B.B. Prasad, R. Madhuri, M.P. Tiwari, P.S. Sharma, Imprinted polymer-carbon consolidated composite fiber sensor for substrate-selective electrochemical sensing of folic acid, Biosens. Bioelectron. 25 (2010) 2140-2148, http://dx.doi.org/10.1016/j.bios. 2010.02.016.

[14] N. Karimian, M.H.A. Zavar, M. Chamsaz, A.P.F. Turner, A. Tiwari, On/off-switchable electrochemical folic acid sensor based on molecularly imprinted polymer electrode, Electrochem. Commun 36 (2013) 92-95, http://dx.doi.org/10.1016/j.elecom.2013. 09.014.

[15] U.D. Uysal, E.M. Oncu-Kaya, M. Tunçel, Determination of folic acid by CE in various cultivated variety of lentils, Chromatographia 71 (2010) 653-658, http://dx.doi. org/10.1365/s10337-010-1555-4.

[16] R.H.F. Cheung, J.G. Hughes, P.J. Marriott, D.M. Small, Investigation of folic acid stability in fortified instant Asian noodles by use of capillary electrophoresis, Food Chem. 112 (2009) 507-514, http://dx.doi.org/10.1016/j.foodchem.2008.05.110.

[17] R. Kalmbach, L. Paul, J. Selhub, Determination of unmetabolized folic acid in human plasma using affinity HPLC, Am. J. Clin. Nutr 94 (2011) 343S-347S, http://dx.doi. org/10.3945/ajen.111.013433.

[18] H.A. Martins-Júnior, A.Y. Wang, J. Alabourda, M.A.F. Pires, O.B. Vega, D.T. Lebre, A validated method to quantify folic acid in wheat flour samples using liquid chromatography: tandem mass spectrometry, J. Braz. Chem. Soc. 19 (2008) 971-977, http:// dx.doi.org/10.1590/S0103-50532008000500024.

[19] A. Leporati, D. Catellani, M. Suman, R. Andreoli, P. Manini, W.M.A. Niessen, Application of a liquid chromatography tandem mass spectrometry method to the analysis of water-soluble vitamins in Italian pasta, Anal. Chim. Acta 531 (2005) 87-95, http://dx.doi.org/10.1016/j.aca.2004.10.006.

[20] A. Rodríguez-Bernaldo De Quirós, C. Castro De Ron, J. López-Hernández, M.A. LageYusty, Determination of folates in seaweeds by high-performance liquid chromatography, J. Chromatogr. A 1032 (2004) 135-139, http://dx.doi.org/10.1016/j.chroma. 2003.11.027.

[21] J. Arcot, A.K. Shrestha, U. Gusanov, Enzyme protein binding assay for determining folic acid in fortified cereal foods and stability of folic acid under different extraction conditions, Food Control 13 (2002) 245-252, http://dx.doi.org/10.1016/S09567135(02)00018-X.

[22] R.J. Uzuriaga-Sánchez, S. Khan, A. Wong, G. Picasso, M.I. Pividori, M.D.P.T Sotomayor, Magnetically separable polymer (Mag-MIP) for selective analysis of biotin in food samples, Food Chem 190 (2016) 460-467, http://dx.doi.org/10.1016/j. foodchem.2015.05.129.

[23] K.M. Diniz, C.R.T. Tarley, Speciation analysis of chromium in water samples through sequential combination of dispersive magnetic solid phase extraction using mesoporous amino-functionalized $\mathrm{Fe} 3 \mathrm{O} 4 / \mathrm{SiO} 2$ nanoparticles and cloud point extraction, Microchem. J 123 (2015) 185-195, http://dx.doi.org/10.1016/j.microc.2015.06.011.

[24] F. Lu, M. Sun, L. Fan, H. Qiu, X. Li, C. Luo, Flow injection chemiluminescence sensor based on core-shell magnetic molecularly imprinted nanoparticles for determination of chrysoidine in food samples, Sensors Actuators B Chem 173 (2012) 591-598, http://dx.doi.org/10.1016/j.snb.2012.07.069.

[25] A. Safavi, A.R. Banazadeh, Catalytic determination of traces of oxalic acid in vegetables and water samples using a novel optode, Food Chem 105 (2007) 1106-1111, http://dx.doi.org/10.1016/j.foodchem.2007.05.007.

[26] A.N. De Oliveira, H. De Santana, C.T.B.V. Zaia, D.A.M. Zaia, A study of reaction between quinones and thiourea: determination of thiourea in orange juice, J. Food Compos. Anal 17 (2004) 165-177, http://dx.doi.org/10.1016/S08891575(03)00107-8.

[27] S. Shi, J. Guo, Q. You, X. Chen, Y. Zhang, Selective and simultaneous extraction and determination of hydroxybenzoic acids in aqueous solution by magnetic molecularly imprinted polymers, Chem. Eng. J 243 (2014) 485-493, http://dx.doi.org/10. 1016/j.cej.2014.01.035.

[28] X.-Y. Gong, X.-J. Cao, Preparation of molecularly imprinted polymers for artemisinin based on the surfaces of silica gel, J. Biotechnol 153 (2011) 8-14, http://dx.doi.org/ 10.1016/j.jbiotec.2011.02.005.

[29] Y.-S. Ho, Review of second-order models for adsorption systems, J. Hazard. Mater 136 (2006) 681-689, http://dx.doi.org/10.1016/j.jhazmat.2005.12.043.

[30] A. Wong, F.M. de Oliveira, C.R.T. Tarley, M. Del Pilar Taboada Sotomayor, Study on the cross-linked molecularly imprinted poly(methacrylic acid) and poly(acrylic acid) towards selective adsorption of diuron, React. Funct. Polym. 100 (2016) 26-36, http://dx.doi.org/10.1016/j.reactfunctpolym.2016.01.006.

[31] Z. Ullah, S. Hussain, S. Gul, S. Khan, F.K. Bangash, Use of HCl-modified bentonite clay for the adsorption of acid blue 129 from aqueous solutions, Desalin. Water Treat 110 (2015) http://dx.doi.org/10.1080/19443994.2015.1027282. 